\title{
Simultaneous Determination of Metronidazole and Diiodohydroxyquine in Bulk Powder and Paramibe Compound Tablets by TLC-Densitometry and HPLC
}

\author{
Hesham Salem ${ }^{1}$, Safaa M. Riad ${ }^{2}$, Mamdouh R. Rezk ${ }^{2}$ and Kholoud Ahmed ${ }^{2 *}$ \\ ${ }^{1}$ Pharmaceutical and Analytical Chemistry Department, Faculty of Pharmacy, October University for Modern Sciences and Arts, $6^{\text {th }}$ of October city, Egypt \\ ${ }^{2}$ Analytical Chemistry Department, Faculty of Pharmacy, Cairo University, Kasr El-Aini Street, 11562 Cairo, Egypt
}

\begin{abstract}
Two sensitive and precise chromatographic methods were developed and validated for simultaneous determination of metronidazole (MTR) and diiodohydroxyquin (DIQ) in pharmaceutical preparation. The techniques adopted for quantification are coupled TLC-densitometry and HPLC. A mixture of chloroform, toluene, ethanol and acetic acid $(9: 9: 1: 1, \mathrm{v} / \mathrm{v} / \mathrm{v} / \mathrm{v})$ was used as the developing solvent for TLC-densitometry. A mixture of methanol and acetonitrile, $(96: 4, \mathrm{v} / \mathrm{v})$ was used as a mobile phase for HPLC at $0.6 \mathrm{~mL} \mathrm{~min}^{-1}$ flow rate and UV detection at 254 $\mathrm{nm}$. Linearity was obtained in concentration range of $0.5-10 \mu \mathrm{g} \mathrm{spot}^{-1}$ for DIQ and 1-20 $\mu \mathrm{g} \mathrm{spot}^{-1}$ for MTR applying TLC-densitometry and $0.005-0.5 \mathrm{mg} \mathrm{mL}^{-1}$ for DIQ and $0.01-0.5 \mathrm{mg} \mathrm{mL}^{-1}$ for MTR applying HPLC. The selectivity of the proposed methods was checked using laboratory prepared mixtures. The proposed methods were successfully applied to the analysis of MTR and DIQ in their mixture and in pharmaceutical dosage forms without interference from other additives.
\end{abstract}

Keywords: Metronidazole; Diiodohydroxyquinoline; TLC-Densitometry; HPLC; Tablets dosage form

\section{Introduction}

Metronidazole (MTR), is 2-(2-methyl-5-nitro-1H-imidazol-1yl) ethanol (Figure 1a). It is used as antibacterial and antiamaebiasis [1]. Metronidazole is metabolized by oxidation to 2-hydroxymethyl metronidazole and 2-methyl-5-nitroimidazol-1-acetic acid, and by conjugation with glucuronic acid. About 70 to $80 \%$ of a dose is excreted in the urine in $48 \mathrm{hr}$ with less than $10 \%$ of the dose as unchanged drug, up to $10 \%$ as conjugated MTR, about $27 \%$ as $2-$ hydroxymethylmetronidazole, $10 \%$ as the conjugated 2-hydroxymethyl metabolite, and $20 \%$ as the acid metabolite [2]. Diiodohydroxyquinoline (DIQ), 5,7-diiodoquinolin-8-ol (Figure $1 \mathrm{~b}$ ). It is widely known by the trade name Diodoquin, is a quinoline derivative which can be used in the treatment of amoebiasis. Iodoquinol is poorly absorbed from the gastrointestinal tract and is amebicidal at the site of infection. It acts by chelating ferrous ions essential for metabolism [3].

The literature survey reveals several analytical methods for quantitative estimation of MTR in body fluids and in pharmaceutical formulations these methods include ultaviolet spectrophotometry [4-6], high-performance liquid formulations (HPLC) $[7,8]$ and voltammetry [9]. Quantitation of metronidazole and spiramycin in human plasma, saliva and gingival crevicular fluid by LC-MS/MS [10]. Simultaneous multi residue determination of metronidazole and spiramycin in fish muscle using high performance liquid chromatography with UV detection [11]. Microsized Graphite Sensors for potentiometric determination of metronidazole and spiramycin [12]. DIQ was determined in pharmaceutical formulations using HPLC [13].

The present work aimed to develop simple instrumental methods for simultaneous determination of MTR and DIQ in combination. These methods include as chromatographic methods; namely, TLCdensitometry method and HPLC [14].

\section{Experimental}

\section{Instruments}

Camag TLC scanner 3S/N 130319 with winCATS software. Camag<smiles>Cc1ncc([N+](=O)[O-])n1CCO</smiles>

Figure 1a: Chemical structure of Metronidazole (MTR).<smiles>Oc1c(I)cc(I)c2cccnc12</smiles>

Figure 1b: Chemical structure of Diiodohydroxyquine (DIQ).

*Corresponding author: Kholoud Ahmed, Pharmaceutical and Analytica Chemistry Department, Faculty of Pharmacy, October University for Modern Sciences and Arts, $6^{\text {th }}$ of October city, Egypt, Tel: +20 1226483727; E-mail: m.habashyyy@hotmail.com

Received December 06, 2012; Accepted December 27, 2012; Published December 30, 2012

Citation: Salem H, Riad SM, Rezk MR, Ahmed K (2012) Simultaneous Determination of Metronidazole and Diiodohydroxyquine in Bulk Powder and Paramibe Compound Tablets by TLC-Densitometry and HPLC. Pharmaceut Anal Acta 3: 201. doi:10.4172/2153-2435.1000201

Copyright: $\odot 2012$ Salem H, et al. This is an open-access article distributed under the terms of the Creative Commons Attribution License, which permits unrestricted use, distribution, and reproduction in any medium, provided the original author and source are credited. 
Citation: Salem H, Riad SM, Rezk MR, Ahmed K (2012) Simultaneous Determination of Metronidazole and Diiodohydroxyquine in Bulk Powder and Paramibe Compound Tablets by TLC-Densitometry and HPLC. Pharmaceut Anal Acta 3: 201. doi:10.4172/2153-2435.1000201

linomat autosampler (Switzerland), Camag microsyringe $(100 \mu \mathrm{L})$. A liquid chromatography consisted of an quaternary pump (Agilent Model G1316A/G1316B), a diode array multiple wavelength detector (Model G1316 C/D and G1365C/D, Agilent 1200 Series), standard and preparation autosamplers (Agilent 1200 series) equipped vacuum degasser, Agilent. Stationary phase $(250 \mathrm{~mm} \times 4.6 \mathrm{~mm}, 10 \mu \mathrm{m}) \mathrm{C}_{18}$ Lichrosorb $^{\mathrm{TM}} 10 \mu \mathrm{m}$ analytical column, Alltech (USA). Mobile phase; methanol and acetonitrile $(96: 4, \mathrm{v} / \mathrm{v})$ isocratically at $0.6 \mathrm{~mL} \mathrm{~min}^{-1}$. The mobile phase was filtered through a $0.45 \mu \mathrm{m}$ millipore membrane filter and was degassed for $\sim 15 \mathrm{~min}$ in an ultrasonic bath prior to use. UVdetection was done at $254 \mathrm{~nm}$. The samples were filtered also through a $0.45 \mu \mathrm{m}$ membrane filter.

\section{Solvents, authentics and pharmaceutical preparation}

Reference metronidazole hydrochloride powder (MTR) and reference diiodohydroxyquine (DIQ) were kindly donated by $\mathrm{Al}$ Qahir Pharmaceuticals Co. The potency was found to be $1002 \mu \mathrm{g} \mathrm{mg}^{-1}$. Pharmaceutical dosage form (Paramibe compound, $500 \mathrm{mg}$ tablets were kindly supplied by Chemical Industries Development (CID) and were claimed to contain $250 \mathrm{mg}$ of MTR and $250 \mathrm{mg}$ of DIQ per each tablet. Methanol and acetonitrile HiPerSolv ${ }^{\circledR}$, HPLC-grade E. Merck (Darmstadt, Germany), BDH-laboratory supplier (Poole, England). De-ionized water: Bidistilled from "Aquatron" Automatic Water Still A4000, Bibbysterillin Ltd. (Staffordshire, UK), methanol analytical grade.

\section{Standard solutions}

MTR standard solution and DIQ standard solution $\left(0.5 \mathrm{mg} \mathrm{mL}^{-1}\right.$ each) in mobile phase for the HPLC method and MTR standard solution $\left(1 \mathrm{mg} \mathrm{mL}^{-1}\right)$ and DIQ $\left(0.5 \mathrm{mg} \mathrm{mL}^{-1}\right)$ in methanol for TLCdensitometric method. The standard solutions were freshly prepared on the day of analysis and stored in a refrigerator to be used within 24 hr.

\section{Procedures}

\section{TLC-densitometric method:}

- Linearity: Aliquots 1-20 $\mu \mathrm{L}$ of MTR standard solution (1 mg $\left.\mathrm{mL}^{-1}\right)$ and DIQ $\left(0.5 \mathrm{mg} \mathrm{mL}^{-1}\right)$ were applied in the form of bands on a TLC plate. The band length was $4 \mathrm{~mm}$ apart from each other and $10 \mathrm{~mm}$ from the bottom edge of the plate. Linear ascending development was performed in a chromatographic tank previously saturated with chloroform, toluene, ethanol and acetic acid (9:9:1:1, v/v/v/v) for $1 \mathrm{hr}$ at room temperature. The developed plates were air-dried and scanned at $311 \mathrm{~nm}$ using deuterium lamp, absorbance mode at $3 \mathrm{~mm} \times 0.45 \mathrm{~mm}$ slit dimension and scanning speed of $20 \mathrm{mms}^{-1}$. Calibration curves relating the optical density of each spot to the corresponding concentration of MTR and DIQ were constructed. The regression equations were then computed for the studied drugs and used for determination of unknown samples containing them (Table 2).

\section{Liquid chromatographic method:}

- Linearity: Portions $0.1-2 \mathrm{~mL}$ from MTR standard solution $\left(0.5 \mathrm{mg} \mathrm{mL}^{-1}\right.$ in the mobile phase) and DIQ $\left(0.5 \mathrm{mg} \mathrm{mL}^{-1}\right)$ were transferred separately into a series of $10-\mathrm{mL}$ volumetric flasks and completed with mobile phase. The contents of each flask were completed to volume with the mobile phase to get the concentrations of $5-1000 \mathrm{mg} \mathrm{mL} \mathrm{m}^{-1}$ of MTR and 5-500 $\mathrm{mg} \mathrm{mL} \mathrm{m}^{-1}$ of DIQ. The samples were then chromatographed using the following chromatographic condition. Stationary phase $(250 \mathrm{~mm} \times 4.6 \mathrm{~mm} 10 \mu \mathrm{m}) \mathrm{C}_{18}$ Lichrosorb $^{\mathrm{TM}} 10 \mu \mathrm{m}$ analytical column, Alltech (USA), mobile phase; methanol and acetonitrile, $(96: 4, \mathrm{v} / \mathrm{v})$. The mobile phase was filtered through a $0.45 \mu \mathrm{m}$ millipore membrane filter and was degassed for about $15 \mathrm{~min}$ in an ultrasonic bath prior to use, flow rate; $0.6 \mathrm{~mL} \mathrm{m^{-1 }}$ [isocratically at ambient temperature $\left(\sim 25^{\circ} \mathrm{C}\right)$ ], with UV-detection at $254 \mathrm{~nm}$. The samples were filtered also through a $0.45 \mu \mathrm{m}$ membrane filter. To reach good equilibrium, the analysis was usually performed after passing $50-60 \mathrm{~mL}$ of the mobile phase, just for conditioning and pre-washing of the stationary phase. The relative peak area ratios (by using $0.04 \mathrm{mg} \mathrm{mL}^{-1}$ MTR and $0.0375 \mathrm{mg} \mathrm{mL}^{-1}$ DIQ as divisor) were then plotted versus the corresponding concentrations of MTR and DIQ to get the calibration graphs and to compute the corresponding regression equations. Concentrations of unknown samples of MTR and DIQ were determined using the obtained regression equations.

Analysis of laboratory prepared mixtures containing different ratios of MTR and DIQ: Aliquots were mixed to prepare different mixtures containing different ratios (1:1, 1:4, 1:3, 2:1) of MTR and

\begin{tabular}{|c|c|c|c|c|}
\hline \multirow{3}{*}{$\begin{array}{l}\text { Parameter } \\
\text { Range }\end{array}$} & \multicolumn{2}{|c|}{ TLC-densitometric method } & \multicolumn{2}{|l|}{ HPLC method } \\
\hline & MTR & DIQ & MTR & DIQ \\
\hline & $1-20 \mu \mathrm{g} \mathrm{spot}^{-1}$ & $0.5-10 \mu \mathrm{g} \mathrm{spot}^{-1}$ & $0.01-1 \mathrm{mg} \mathrm{mL}^{-1}$ & $0.005-0.5 \mathrm{mg} \mathrm{mL}^{-1}$ \\
\hline Slope & 0.079 & 0.438 & 39.69 & 38.16 \\
\hline Intercept & 0.092 & 0.738 & -0.486 & 0.011 \\
\hline Mean & 99.87 & 100.15 & 99.92 & 100.15 \\
\hline \pm S.D. & 0.365 & 0.593 & 0.433 & 0.483 \\
\hline Variance & 0.133 & 0.352 & 0.187 & 0.233 \\
\hline Coefficient of variation & 0.365 & 0.592 & 0.433 & 0.482 \\
\hline Correlation coefficient (r) & 0.9998 & 0.9999 & 0.9999 & 0.9999 \\
\hline R.S.D. (\%) & 0.365 & 0.592 & 0.433 & 0.482 \\
\hline
\end{tabular}

Table 1: Assay parameters and validation sheet for determination of metronidazole (MTR) and diiodohydroxyquine (DIQ).

\section{Preparation}

TLC-densitometric method

HPLC method

Paramibe compound tablets $(0.5 \mathrm{~g})$

MTR mean \pm S.D.

$99.67 \pm 0.165$

DIQ mean \pm S.D.

$99.61 \pm 0.098$

$99.995 \pm 0.313$

$100.008 \pm 0.121$

Table 2: Determination of MTR and DIQ in paramibe compound tablet by proposed methods. 
DIQ, respectively. The concentrations were calculated from the corresponding regression equations (Table 3).

Assay of pharmaceutical formulations (Paramibe compound tablets): Twenty tablets were weighed and grinded to determine the average weight per tablet. Aliquot of the powder tablet equivalent to $250 \mathrm{mg}$ of MTR and DIQ each was extracted by shaking with methanol for 15 minutes then the volume was completed to the mark with methanol to get a concentration of $1 \mathrm{mg} \mathrm{mL}^{-1}$ of MTR and DIQ and proceed as described under each method.

\section{Results and Discussion}

\section{TLC-fractionation}

TLC-monitoring of MTR and DIQ was done on thin layer plates of silica gel F254 using chloroform, toluene, ethanol and acetic acid (9:9:1:1, v/v/v/v) as the developing solvent. The developed plates were visualized under short UV-lamp. MTR $\left(R_{f}\right.$ value $\left.=0.13\right)$; could be separated from DIQ $\left(\mathrm{R}_{\mathrm{f}}\right.$ value $\left.=0.741\right)$.

\section{Chromatographic methods}

TLC-densitometry: A TLC-densitometric method is described for the determination of MTR in the presence of DIQ without prior separation. Different solvent systems were tried for the separation of MTR and DIQ. Satisfactory results were obtained by using a mobile phase composed of chloroform, toluene, ethanol and acetic acid (9:9:1:1, $\mathrm{v} / \mathrm{v} / \mathrm{v} / \mathrm{v})$, where $\mathrm{R}_{\mathrm{f}}=0.13$ and 0.740 for MTR and DIQ, respectively. The separation allows the determination of MTR with no interference from DIQ (Figure 4). The linearity was confirmed by plotting the measured peak area versus the corresponding concentrations at $311 \mathrm{~nm}$ over a range of 1-20 $\mu \mathrm{g} \operatorname{spot}^{-1}$ and $0.5-10 \mu \mathrm{g} \mathrm{spot}^{-1}$ for MTR and DIQ, respectively where a linear response was obtained (Figures 2 and 3). The regression equation was found to be: $\mathrm{A}=0.079 \mathrm{C}+0.092, \mathrm{r}=0.9998$; where $\mathrm{A}$ is the area under the peak and $\mathrm{C}$ is the concentration of MTR in $\mu \mathrm{g} \operatorname{spot}^{-1}$ and $\mathrm{r}$ is the correlation coefficient and for DIQ, the regression

\begin{tabular}{|l|ll|}
\hline Method & TLC-densitometric method & HPLC method \\
\hline MTR (Mean \pm SD) & $99.97 \pm 0.320$ & $100.10 \pm 0.469$ \\
\hline DIQ (Mean \pm SD) & $100.40 \pm 0.253$ & $100.28 \pm 0.085$ \\
\hline
\end{tabular}

Table 3: Determination of metronidazole and diiodohydroxyquine in laboratory prepared mixtures by the proposed methods.

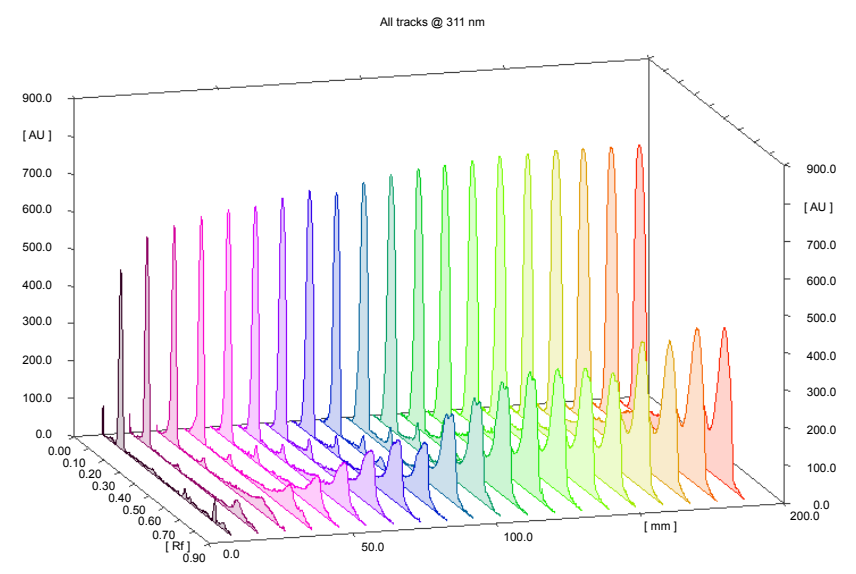

Figure 2: Linearity of MTR (1-20) $\mu \mathrm{g} \mathrm{spot}^{-1}\left(\mathrm{R}_{\mathrm{f}}\right.$ value=0.13) DIQ $(0.5-10) \mu \mathrm{g}$ $\operatorname{spot}^{-1}\left(R_{\mathrm{f}}\right.$ value $\left.=0.74\right)$ measured at $311 \mathrm{~nm}$.

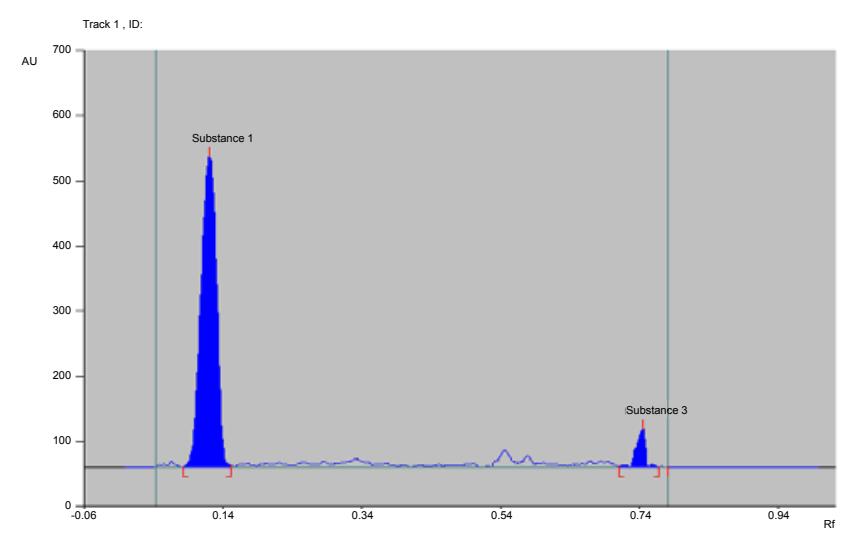

Figure 3: Separation of MTR $\left(R_{f}\right.$ value $\left.=0.13\right)$ from DIQ $\left(R_{f}\right.$ value=0.74) upon using chloroform+toluene+ethanol+acetic acid $(9: 9: 1: 1, \mathrm{v} / \mathrm{v} / \mathrm{v} / \mathrm{v})$.

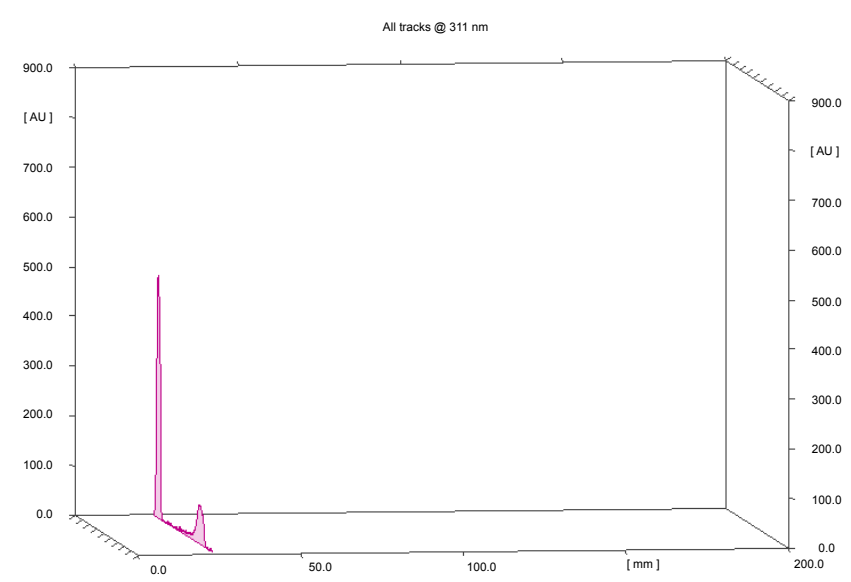

Figure 4: Separation of MTR $\left(R_{f}\right.$ value $\left.=0.13\right)$ from DIQ $\left(R_{f}\right.$ value $\left.=0.74\right)$.

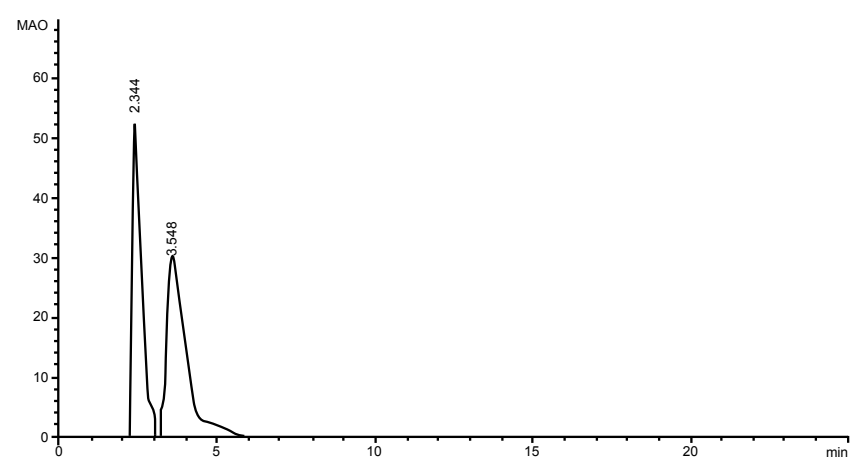

Figure 5: Liquid chromatographic separation of metronidazole (2.344 $\mathrm{min})$ and diiodohydroxyquine (3.548 $\mathrm{min}$ ) upon using methanol+acetonitrile, (96:4, $\mathrm{v} / \mathrm{v})$ as a mobile phase.

equation was found to be: $A_{2}=0.438 C_{2}+0.738, r_{2}=0.9999$; where $A_{2}$ is the area under the peak and $\mathrm{C}_{2}$ is the concentration of DIQ in $\mu \mathrm{g} \mathrm{spot}^{-1}$ and $r_{2}$ is the correlation coefficient (Table 4).

The precision of the proposed method was checked by the analysis of different concentrations of authentic samples in triplicates. The 
Citation: Salem H, Riad SM, Rezk MR, Ahmed K (2012) Simultaneous Determination of Metronidazole and Diiodohydroxyquine in Bulk Powder and Paramibe Compound Tablets by TLC-Densitometry and HPLC. Pharmaceut Anal Acta 3: 201. doi:10.4172/2153-2435.1000201

Page 4 of 4

\begin{tabular}{|c|c|c|c|c|c|c|}
\hline \multirow{3}{*}{\begin{tabular}{|l|} 
Parameters \\
Mean
\end{tabular}} & \multicolumn{2}{|c|}{ TLC-densitometry } & \multicolumn{2}{|c|}{ HPLC } & \multirow{3}{*}{$\begin{array}{c}\text { official method }^{1} \\
\text { MTR }\end{array}$} & \multirow{3}{*}{$\begin{array}{c}\text { Reference method } \\
\text { DIQ }\end{array}$} \\
\hline & MTR & DIQ & MTR & DIQ & & \\
\hline & 99.87 & 100.15 & 99.92 & 100.15 & & \\
\hline \pm S.D & 0.365 & 0.593 & 0.433 & 0.483 & 0.507 & 0.641 \\
\hline Variance & 0.133 & 0.352 & 0.187 & 0.233 & 0.257 & 0.411 \\
\hline F-test & $\begin{array}{c}1.93 \\
(2.71)^{\mathrm{a}}\end{array}$ & $\begin{array}{c}1.17 \\
(2.71)^{\mathrm{a}}\end{array}$ & $\begin{array}{c}1.37 \\
(4.88)^{\mathrm{a}}\end{array}$ & $\begin{array}{c}1.76 \\
(4.95)^{\mathrm{a}}\end{array}$ & & \\
\hline Student's $t$-test & $\begin{array}{c}0.899 \\
(2.06)^{\mathrm{a}}\end{array}$ & $\begin{array}{c}0.102 \\
(2.06)^{a}\end{array}$ & $\begin{array}{c}0.583 \\
(2.18)^{a}\end{array}$ & $\begin{array}{c}0.094 \\
(2.20)^{\mathrm{a}}\end{array}$ & & \\
\hline $\mathrm{N}$ & 20 & 20 & 8 & 7 & 6 & 6 \\
\hline
\end{tabular}

aThe values in the parenthesis are corresponding the oretical t- and F-values at $P=0.05$ [14]

Table 4: Statistical comparison for the results obtained by the proposed methods and the official method for analysis of MTR and official method for analysis of DIQ.

mean percentage recovery was found to be $99.87 \pm 0.365$ for MTR and $100.15 \pm 0.539$ for DIQ (Table 1 ).

High-performance liquid chromatography: A simple isocratic high-performance liquid chromatographic method was developed for the determination of MTR and DIQ in pure form and in pharmaceutical preparation using $(250 \mathrm{~mm} \times 4.6 \mathrm{~mm}, 10 \mu \mathrm{m}) \mathrm{C}_{18}$ lichrosorb $^{\mathrm{TM}}$ analytical column. The mobile phase was consisting of methanol and acetonitrile, $(96: 4, \mathrm{v} / \mathrm{v})$. The mobile phase was chosen after several trials to reach the optimum stationary/mobile-phase matching. The average retention times under the conditions described are 2.344 min for MTR, 3.548 min for DIQ (Figure 5). One sample can be chromatographed in less than 6 min. Peak purity was confirmed for the HPLC peaks of both MTR and DIQ by a pilot run using a photodiode array detector. Calibration graph was obtained by plotting the relative peak area ratios (by using $0.04 \mathrm{mg} \mathrm{mL}^{-1}$ MTR and $0.0375 \mathrm{mg} \mathrm{mL}^{-1} \mathrm{DIQ}$ as divisor) against concentration of MTR and DIQ $\left(\mathrm{mg} \mathrm{mL}^{-1}\right)$. Linearity range was found to be $0.01-1 \mathrm{mg} \mathrm{mL}^{-1}$ for MTR and $0.005-0.5 \mathrm{mg} \mathrm{mL}^{-1}$ of DIQ. The regression equation for MTR: $\mathrm{A}=39.69 \mathrm{C}-0.486(\mathrm{r}=0.9999)$ where A is the relative peak area ratio, $\mathrm{C}$ is the concentration of MTR $\left(\mathrm{mg} \mathrm{mL}^{-1}\right)$ and $\mathrm{r}$ is the correlation coefficient and for DIQ $\mathrm{A}_{2}=38.16 \mathrm{C}_{2}+0.011$ $(r=0.9999)$. The mean percentage recovery of pure sample was found to be $99.92 \pm 0.433$ for MTR and $100.15 \pm 0.483$ for DIQ (Table 1).

\section{Conclusion}

The suggested methods are found to be sensitive and precise. Application of the proposed methods to the analysis of MTR and DIQ in their pharmaceutical formulation shows that excipient do not interfere with the determination. The proposed methods can be used for routine analysis of metronidazole and diiodohydroxyquine in quality control laboratories.

\section{References}

1. British pharmacopoeia (2009) vol. I \& II, pp.3952.

2. Galichet LY (2005) Clarke's Analysis of Drugs and Poisons. (3rdedn), Pharmaceutical Press, London, UK.

3. Sweetman S (2005) Martindale: The complete drug reference, Pharmaceutical Press, London, UK

4. Rehman AU, ljaz AS, Raza A (2005) Spectrophotometric determination of metronidazole in pharmaceutical pure and dosage forms using p-benzoquinone. Journal of the Iranian Chemical Society 2: 197-202.

5. Siddappa K, Mallikarjun M, Reddy PT, Tambe M (2008) Spectrophotometric determination of metronidazole through Schiff's base system using vanillin and PDAB reagents in pharmaceutical preparations. Eclet Quím 33.

6. Adegoke OA, Umoh OE (2009) A new approach to the spectrophotometric determination of metronidazole and tinidazole using p-dimethylaminobenzaldehyde. Acta Pharm 59: 407-419.

7. Mustapha KB, Odunola MT, Garba M, Obodozie O (2006) Rapid, cost-effective liquid chromatograghic method for the determination of metronidazole in biological fluids. Afr J Biotechnol 5: 1188-1191.

8. Cox S, Allender MC, Yarbrough J (2009) Determination of metronidazole in adult artemia using high performance liquid chromatography. J Liq Chromatogr Relat Technol 33: 89-96.

9. Bartlett PN, Ghoneim E, El-Hefnawy G, El-Hallag I (2005) Voltammetry and determination of metronidazole at a carbon fiber microdisk electrode. Talanta 66: 869-874.

10. Sagan C, Salvadora A, Dubreuil D, Poulet PP, Duffaut D, et al. (2005) Simultaneous determination of metronidazole and spiramycin I in human plasma, saliva and gingival crevicular fluid by LC-MS/MS. J Pharm Biomed Anal 38: 298-306.

11. Maher HM, Youssef RM, Khalil RH, El-Bahr SM (2008) Simultaneous multiresidue determination of metronidazole and spiramycin in fish muscle using high performance liquid chromatography with UV detection, J Chromatogr B Analyt Technol Biomed Life Sci 876: 175-181.

12. Khattab FI, Ramadan NK, Hegazy MA, Ghoniem NS (2011) Microsized Graphite Sensors for Potentiometric Determination of Metronidazole and Spiramycin. Portugaliae Electrochimica Acta 29: 79-90.

13. Gomaa ZS (1987) Determination of Diiodohydroxyquin in Dosage Forms by High Performance Liquid Chromatography. Journal of Liquid Chromatography 10: $1175-1185$.

14. Spiegel M, Stephns L (1999) Schaum Outline of Theory and Problems of Statistics, Schaum Outline Series, NY, USA. 